\title{
EVALUATION OF SUBSIDIZED RICE (RASKIN) PROGRAM IMPLEMENTATION WITH LABOUR-INTENSIVE PATTERNS OF FOOD SECTOR IN NORTH CENTRAL TIMOR REGENCY
}

\author{
Kono Yoaneta Sanit*, Pandie David B., Djani William \\ Master Program in Administrative Science, Post-Graduate Program, \\ University of Nusa Cendana, Kupang, East Nusa Tenggara, Indonesia \\ *E-mail: lorakono042@gmail.com
}

\begin{abstract}
Learning from previous experience, various programs of poverty alleviation which are the policies of either central, provincial and local government seem to only spoil the community with a variety of assistance that tends to lull people. Based on this fact, the local government of North Central Timor Regency runs a public policy namely Raskin (Beras Raskin or subsidized rice) Program converted to an empowerment program packaged with LabourIntensive Patterns of food sector (PKP - Padat Karya Pangan). Besides, an analysis needs to be done on the success of PKP program as one of the government policies in the effort of poverty alleviation. This research aimed to describe: (1) the socialization and data collection implementation of the Raskin Program with PKP Patterns, (2) the accurate targets, amount, time, quality and administration of the Raskin program implementation with PKP Patterns, (3) internal and external obstacles in the implementation of Raskin program with PKP Patterns, and (4) the proposed evaluation model of the Raskin program with PKP Patterns. This research used a qualitative research method with a descriptive approach. The implementation of this research was focused on North Central Timor Regency, East Nusa Tenggara Province. Data were collected using various techniques covering interviews, documentation and observation. The data were then analyzed using several techniques covering data collection, data reduction, data presentation, and conclusion/ verification. From the results of this research, the researchers tried to summarize the proposed evaluation model in the implementation of the Raskin program with PKP patterns in North Central Timor Regency. The evaluation model is a combination of evaluation teams, in this case referring to the Technical Teams at the village, district and regency levels. Moreover, the evaluation model involves the customary leaders in each village governed in the village regulations containing the rights and obligations as well as sanctions for Beneficiary Families (KPM Keluarga Penerima Manfaat) if they neglect the plantation works or if they do not conduct the plantation works in accordance with the working norms defined in the Technical Guidance of the Department of Agriculture of North Central Timor Regency.
\end{abstract}

\section{KEY WORDS}

Evaluation, program, subsidized rice, food, regency.

Most Indonesians consume rice as the staple food. Thus, rice becomes a very strategic national commodity. The President instructs the Minister, the Heads of certain non-ministerial Government Agencies, the Governors and Regents / Mayors throughout Indonesia to make efforts to increase farmers' income, food security, rural economic development and national economic stability. Specifically, the Indonesian Bureau of Logistics is instructed to provide and distribute subsidized rice for those with low income and food insecurity in which the provision prioritizes grain/rice produced from domestic farmers.

To support the food sovereignty, the Government through the Coordinating Ministry for Human Development and Cultural Affairs is responsible for coordinating, synchronizing and controlling the implementation of Social Protection Programs, including the policy of the Raskin (subsidized rice) program for low-income communities. The implementation of the Raskin (subsidized rice) program has a mechanism which is a reference or standard of the 
national Raskin program implementation so that it has the same spirit in its implementation throughout Indonesia.

The Government of East Nusa Tenggara Province is one of the Raskin programtargeted areas because it is an area with a great number of poor population and its dry land is potential for agricultural development. People living in this dry land area, at a certain time, lack food, especially rice. The most noticeable situation is during the period of the long dry season from March to November. This situation leads the Government to intervene with the assistance of subsidized rice.

According to the statistical data of 2014, North Central Timor Regency is one of the areas in East Nusa Tenggara Province that has a large dry area of 253,120 ha or about $65.79 \%$ of the total area of the Regency (The Central Bureau of Statistics of North Central Timor Regency, 2015), which becomes a potential for the Local Government. Therefore, the Local Government is required to empower the community by looking at the existing potential. Forms of the empowerment should be in accordance with the potentials, problems, and needs of the local community. As one of the regencies in East Nusa Tenggara Province receiving the Raskin program nationally, the Government of North Central Timor Regency changed the Raskin program into the one with Labour-Intensive Patterns of Food as the superior program of the Government of North Central Timor Regency. All of it is contained in the Five Strategic Programs of North Central Timor Regency covering agricultural development program, educational development program, health development program, cooperative and SME empowerment program as well as the program of natural resource and environmental management optimization (the Government of North Central Timor Regency, 2011). In the framework of community empowerment on the dry land in North Central Timor Regency, the Local Government applies for the Raskin Program with Labour-Intensive Patterns of Food (PKP).

\section{LITERATURE REVIEW}

Strategic Decision-Making. Decision-making has significance for the advancement of an organization, particularly since the future of an organization is largely determined by current decision-making. According to Terry (1989 in Mulyono, 2009: 67), decision-making is the selection of certain alternative behaviours (actions) of two or more alternatives that exist. Meanwhile, S.P Siagian (in Mulyono, 2009) stated that decision-making is a systematic approach to the nature of alternatives faced and a process of taking actions that are appropriate based on the calculation.

There are several theories of decision-making (Mulyono, 2009). The first is Comprehensive Rational Theory, which demands irrational things in decision-makers. The assumption is that a decision maker has enough information about various alternatives so as to take into account the principle of benefit costs and consider many interrelated issues. The second is Incremental Theory in which decisions are made by avoiding many issues that must be considered and it is a model often adopted by the Government officials in making decisions. Incremental decisions provide a basic guide and enlarge the chance of fundamental decisions after they are reached. The third is Integrated Observation Model, which is essentially a compromise approach combining the use of a comprehensive rational model and incremental model in the decision-making process.

Theory of Community Empowerment. In relation to the meaning of community empowerment concept, Winarni revealed that the core of empowerment consists of three matters covering development (enabling), potential or power strengthening (empowering), and self-reliance realization (Winarni, 1998:75). Community empowerment is also a form of human-centred development. Moreover, community empowerment is also a form of planned development that is in line with the potentials, problems and needs of the community. Empowerment is aimed at making communities powered, competitive and independent.

According to Oos M.Anwas (2014), the principles of empowerment as a reference to implement empowerment correctly are that: (1) empowerment should be done in a democratic way and without coercion elements, (2) empowerment activities should be 
undertaken based on the target needs, problems, and potentials, (3) empowerment targets are the subjects or actors in the empowerment activities, (4) empowerment means to reestablish values, cultures and local wisdom that have noble values in communities, (5) empowerment is a process that takes time, so it is done gradually and continuously, (6) guidance or coaching activities need to be done wisely, gradually and continuously; (7) empowerment cannot be done from one aspect only, but it needs to be holistic to all aspects of life in communities, (8) empowerment needs to be done to women especially teenagers and young mothers, (9) empowerment should make people have a habit to keep learning, and (10) empowerment needs to pay attention to the existence of cultural diversity. Overall, empowerment must involve various parties existing and related to communities.

Furthermore, according to Kartasasmita (1995:95) in 'Community Empowerment with Development Concept Rooted in Communities', the efforts of empowering people must be done through three ways: (1) creating an atmosphere or climate that allows the community potentials to grow, (2) understanding the essence of self-reliance and community empowerment that the belief and potential of self-reliance of each individual need to be empowered, (3) strengthening the potential or power of communities by implementing concrete steps, accommodating inputs, providing physical and social infrastructure and targets that can be accessed by the lowest layers of communities.

Theory of Public Policy Evaluation. Evaluation is one of the levels in a public policy process. According to the definition, the word of 'evaluation' has a similar meaning to 'assessment' or 'appraisal'. Meanwhile, according to the term, evaluation is a planned activity to know the state of an object by using an instrument and then the result is compared with the benchmark to obtain conclusions (Thoha, 1991:1). Meanwhile, according to Wibawa (1994:9), policy evaluation is aimed at identifying four aspects, namely: (1) policy-making process, (2) implementation process, (3) policy consequences, and (4) policy impact effectiveness. Furthermore, he stated that public policy evaluation has four functions, covering: (a) Explanation, in which evaluation can photographed the reality of program implementation and make a generalization about relationship patterns between various dimensions of the observed reality, (b) Compliance, in which evaluation can suggest whether the actions taken by the actors (both bureaucracy and other actors) are in accordance with the standards and procedures established by the policy, (c) Audit, in which evaluation can show whether the outputs truly reach the policy target groups, or whether there is a leak or aberration, (d) Accounting, in which evaluation can reveal socio-economic consequences of the policy.

The policy evaluation criteria according to Dunn (1987:170) are: (1) Relevance, in which evaluation should provide information needed by decision makers and other policy actors as well as answer the right questions at the right time, (2) Significance, in which evaluation should provide new and important information for policy actors to move beyond what they have assumed to be clear and explicit, (3) Validity, in which evaluation should provide a persuasive and balanced consideration concerning the concrete results of a policy or program, (4) Reliability, in which evaluation should contain evidence that conclusions are not based on the information obtained from incomplete and inconsistent measurement procedures, (5) Objectivity, in which evaluation should report conclusions and supporting information that are complete and unbiased, i.e information that allows the evaluators to reach the same conclusions, (6) Timeliness, in which evaluation should make information available at the time of decision-making, (7) Effectiveness, in which evaluation should provide information that is understandable for decision makers and other policy actors.

Subsidized Rice (Raskin) Program. The program of providing subsidized (cheap) rice for poor families, called permanently as Raskin program, has been running since the 1997 monetary crisis, characterized by decreased food production and increased rice prices. Raskin program is one of the Pro Programs of Social Assistance and Protection for Cluster 1-People. The program is one of the poverty alleviation programs through which the Government wants to assist the economic expenditure of the poor in the fulfillment of their staple food needs as a result of the financial and monetary crisis of the world leading to an economic gap in the country (the Coordinating Ministry for People's Welfare at the event of 
launching Raskin Program in 2010). The initial goal of making Raskin Program as a temporary program that is only fulfilling the people's food availability during the economic crisis seems to be increasingly difficult to pursue currently because as the time passes, such a government policy has been perceived by the community as the "god of help" of their lives. In 2013, the number of subsidies ruled out from the APBN for Raskin Program was recorded at 17.2 trillion rupiahs.

The current principles for Raskin Program implementation are based on two sources. The first is Presidential Regulation No. 15 of 2010 on the Acceleration of Poverty Alleviation, in which 1) the National Team for the Acceleration of Poverty Reduction (TNP2K) is assigned to improve the targeting and implementation of family/cluster-based poverty alleviation programs; 2) a working team for controlling Cluster 1 is established, chaired by the Executive Secretary of the National Team for the Acceleration of Poverty Reduction (TNP2K). The second is Decree of the Coordinating Minister of People's Welfare No.57 of 2012 on the Central Coordinating Team for the Raskin Program, in which 1) it arranges the formation of the membership structure, duties, and secretariat of the Central Coordinating Team for the Raskin Program; 2) It determines costs to support the Central Coordinating Team for the Raskin Program charged to the operational budget of the Bureau of Logistics' subsidized rice (Raskin) and/or the State Budget (APBN).

Raskin Distribution with Labour-Intensive Patterns of Food (PKP). The management of the Raskin Program using Labour-Intensive Patterns of Food is the maximal effort to make the Raskin management become effective and efficient, by giving more weight through the organization of farmer families, mutual cooperation in managing land for agricultural business, coaching/accompaniment, meetings, coordination, monitoring and evaluation to strengthen the impact of cooperation towards food security and food sovereignty of the farmer families (the Department of Agriculture of Food Crops and Horticulture of North Central Timor Regency, 2014)

The purpose of rice management for poor households with Labour-Intensive Patterns of Food is to provide rice for poor households by doing agricultural works so that it can increase the production and productivity that are more profitable for poor families at the same time. Meanwhile, the long-term goal of rice management for poor households with the Labour-Intensive Patterns of Food is "to achieve food security and food sovereignty for poor farmer families by providing new sources of livelihoods sustainably, to encourage the dissemination of eco-friendly farming systems through rice subsidy and to optimize rice management for poor families in North Central Timor Regency.

The principles adopted in the management of rice for poor households with the LabourIntensive Patterns of Food according to the Department of Agriculture of Food Crops and Horticulture of North Central Timor Regency, 2014 are: Participatory, in which each poor family actively participates in planning, implementing, monitoring and evaluating the whole process of the Labour-Intensive Patterns of Food; Equity, in which each poor family gets a ration of rice and accompaniment (coaching) without any discrimination of gender, age or social status; Justice, in which each poor family has the right of getting a ration of rice with the same volume in accordance with the minimum standard of processed land; Sustainability, in which each poor family should work on the settled farm continuously every year. The settled farm development of poor families in farmer groups every year is 0.25 ha. They work in rotation to develop the farming according to the Labour-Intensive Patterns of Food.

\section{METHODS OF RESEARCH}

This research used a qualitative research method with a descriptive approach. The researchers chose North Central Timor Regency, East Nusa Tenggara Province as the location studied. The data used in this research were collected from the year of 2011 to 2016, since the implementation of the Raskin Program with Labour-Intensive Patterns of Food. The respondents and informants of this research were farmers who implemented the Raskin Program with Labour-Intensive Patterns of Food as well as the technical actors and 
decision makers. Data were collected using various techniques covering interviews, documentation and observation. The data were then analyzed using several techniques covering data collection, data reduction, data presentation, and conclusion/ verification Data validity tests of this research consisted of data credibility and objectivity tests. The data credibility test of this research was done with prolonged observation, increased perseverance, triangulation and discussion.

\section{RESULTS AND DISCUSSION}

Implementation of Raskin Program Socialization with PKP Patterns. The person in charge of the Raskin management with PKP patterns (Labour-Intensive Patterns of Food) in the regency level is the Regent itself while that in the level of the district is the head of the district and that in the level of village / sub-district is the head of the village or sub-district. According to the Technical Guidance from the Department of Agriculture, the Coordination Team at the district level where the district head is responsible for the implementation of the Raskin management with PKP Patterns forms a District-Level Coordination Team. The tasks and roles of the District-Level Coordination Team include: 1) socializing policies and mechanisms for the Raskin management with PKP Patterns to the village/ sub-district apparatus and other parties within the concerned area; 2) coaching the implementation of the Raskin management with the PKP Patterns; 3) monitoring and evaluating the implementation of Raskin management with the PKP Patterns periodically.

From the results of research conducted by the researchers in the selected four villages of two districts by interviewing the informants, it was found that the socialization from the coordination team and technical team at the Regency, district, sub-district levels have been implemented in accordance with the technical guidance from the Department of Agriculture. Furthermore, it was analyzed that after a program or policy has been planned and launched, the next step to do was socializing it to the public. In this case, the establishment of the technical team and coordination team starting from the regency to sub-district level should be solid and strong. Besides, the teams have to be able to implement the Raskin Program with PKP Patterns. Any good program without any socialization will never be meaningful.

It can be concluded that the socialization of the Raskin Program with PKP Patterns has been implemented as optimally as possible starting from the regency to village/sub-district level. Although there are still many obstacles in the field, the socialization should continue to be implemented so that the final goal of the program can be achieved.

Data Collection of Raskin Recipients with PKP Patterns. Data collection or data verification of Beneficiary Families (KPM - Keluarga Penerima Manfaat) was done by the Village/Sub-district Committees and Field Extension Officers, known by the Village/Subdistrict Head. The data verification was done using census method for all the Beneficiary Families of the PKP Patterns. Technical teams of the regency and districts were involved in the villages/sub-districts as needed. The data collected include: a) the names of Family Heads involved in the activities of Raskin Program with PKP Patterns; b) the residential address according to the applicable Identification Card; $c)$ their job performance according to the job type of PKP each year (volume of work, agricultural production and long life crops); d) ensuring that the Beneficiary Families are not Civil Servants (PNS), members of Indonesian National Army (TNI) / Police of the Republic of Indonesia (POLRI), entrepreneurs, private employees (BUMN/ BUMD, $L B H)$, retired Civil Servants (PNS) and retired TNI/POLRI; e) ensuring the involvement of the Beneficiary Families of the PKP Patterns in the following year; f) ownership of land/land area. By the results of the data collection, the real data of Beneficiary Families of the PKP Pattern were then published.

Based on the findings of this research, those kinds of data have a very important function for the performance and smoothness of the Raskin Program with PKP Patterns. By the data collection carried out by the village committees, decisions could be made and the beneficiary families of the Raskin Program with PKP Patterns could be determined. After determining the beneficiary families of the Raskin Program with PKP Patterns, the next step was related to what would be conducted by the beneficiary families of the Raskin Program in 
accordance with the Technical Guidance that has been established, starting from land management, terracing making, seasonal and long life crop planting, intercropping and weeding, and long general crop treatment.

It can be concluded that data collection has a big influence on the success of Raskin Program with the PKP Patterns. All activities of the Raskin Program implementation with the PKP Pattern are made in the form of data. The initial data collection was the verification of the Raskin Program with the PKP Patterns, followed with the potentials owned, planned activities according to Beneficiary Families, the district's activity planning recaps, the regency's activity planning recaps, the list of job performance and distribution of the Raskin with the PKP Patterns, the report recaps of the activity realization and distribution of the Raskin with the PKP Patterns, the list of job performance and distribution of the Raskin at the district level, the list of job performance and distribution of Raskin at the regency level and, the last, the list of the recaps of job performance and distribution of Raskin with the PKP Pattern. Indeed, in the implementation of data collection in the field, there were obstacles faced, mostly caused by the lack of understanding of the committees in filling the existing formats. However, it did not give a big impact hindering the implementation of PKP programs since the technical personnel, i.e farmer orderlies and extension officers, always accompany and coach for the implementation in the field.

Accurate Recipient Targets of Raskin Program with PKP Patterns. This stage is a realization of the goal of North Central Timor Regency Government to make free Raskin (subsidized rice) as a motivation for the poor. The Government expects that the Raskin Program can empower the people, setting them free from the shackles of the existing poverty. This stage of implementation becomes interesting because those involved in the PKP Program are not only the people whose names are listed as Targeted Households for the Raskin, which in 2017 called as Beneficiary Families but all farmers involved in the PKP Program. The Local Government has a purpose to use free Raskin as a medium to build the economic power of the farmer community as a whole.

The results of this study found that the targets in the implementation of the Raskin Program with PKP Patterns in North Central Timor Regency as determined in the Technical Guidance have mostly been accurate but there are also some that have not. This is caused by several obstacles emerging in the field, one of which is the absence of firmness from the village government in encouraging Beneficiary Families to truly implement the plantation management in accordance with the norms and provisions that exist in the Technical Guidance of Raskin Distribution with the PKP Patterns.

Accurate Amount of Raskin with PKP Patterns. According to the standard of the Coordinating Ministry of People's Welfare, each Targeted Household gets a ration of $15 \mathrm{~kg}$ rice per month. However, because, in North Central Timor, there has been converted into Labour-Intensive Patterns of Food $(P K P)$, it is not absolute that each Beneficiary Family gets $15 \mathrm{~kg}$ rice per month. In contrast, the ration of subsidized rice they got was based on the data verification result concerning Beneficiary Families of the PKP program carried out by the Field Guides/ Facilitators assisted by the village committees and field extension officers, known by the village head. From the findings of this research, it was analyzed that the Government policy, in which the Regent of North Central Timor converted the Raskin to the PKP Pattern, is one of the poverty eradication programs through community empowerment by looking at the potential owned by the community itself and also the potential of the region.

Based on the findings, it can also be concluded that the amount of subsidized rice received by the Beneficiary Families varies, in line with the conditions of each Beneficiary Family's plantation. It is stated in the Technical Guidance of the PKP Program. The Raskin management with the PKP Patterns is different from the national Raskin Program. The management of national Raskin Program is only temporary while that with the PKP Patterns is aimed at fulfilling the long-term food needs of the Beneficiary Families. However, in the implementation in the field, subsidized rice is still distributed evenly without seeking or inspecting whether the existing plantation meets the criteria for the PKP program. Based on the results, the amount of the Raskin of PKP Patterns received by the Beneficiary Families was less than that of the national Raskin. This is because the purpose of national Raskin is 
only to meet the food needs temporarily while that of Raskin with Food Labour-Intensive Pattern answers the needs of food until the farmers get a pension that is through long life crops.

Timeliness of Raskin Reception with PKP Patterns. The initial and main purpose of the distribution of Raskin with PKP Patterns for low-income Beneficiary Families is to reduce the burden of the Beneficiary Families' expenditure in meeting the needs of rice. Nevertheless, nationally, the policy implementation of subsidized rice procurement and distribution is done by the Indonesian Bureau of Logistics Public Corporation. Meanwhile, the authority of the rice procurement and the purchase price determination from the Government are under the coordination of the Coordinating Ministry of People's Welfare. From several objectives of Raskin program policy, the Coordinating Ministry of People's Welfare has a responsibility to assist the fulfilment of food needs and reduce the Targeted Households' expenditure. With the Raskin program, the Targeted Households can reduce their expenditure to buy rice, which is the people's basic necessity. In other words, the daily needs of rice must be fulfilled.

From the findings of this research, it was analyzed that the Raskin distribution from the Indonesian Bureau of Logistics to Beneficiary Families was still far from the expectation and the regulation of Raskin management. Raskin, which actually should be received every month, was only distributed twice in a year to the Beneficiary Families due to various factors. This actually has been going on long before the existence of Raskin Program with the PKP Patterns. It can be concluded that the Raskin distribution is not on time due to several factors. However, looking back to the main goal of Raskin Program with the PKP Patterns, the main point is the empowerment of the farmer community in processing the land so that the ultimate goal of this program related to the farmer pension can be realized.

Quality Accuracy. The program implementation is said to be accurate if the rice is met the medium quality requirement, in which the rice should be in a good condition and not contaminated (or attacked by pest/plant disease) in accordance with the quality standard of the Government's rice purchase as governed in legislation. Based on the description and results of interviews above, it was analyzed that the subsidized rice (Raskin) received and consumed by the Beneficiary Families was far from the premium rice standards. However, it has been regulated in the Technical Guidance that rice which does not meet the standards can be returned and exchanged. This is the responsibility of the Technical teams at the district and village levels who have the responsibility to accompany/ coach for the distribution of the subsidized rice (Raskin).

Furthermore, it can be concluded that the quality of Raskin received by the Beneficiary Families is far from the standard quality determined by the Government. The low quality of rice is highly regrettable since it turns out that the Government does not really control the standard quality of the subsidized rice although it has been regulated in the General Guideline of National Raskin and the Presidential Instruction No. 3 of 2012 (at some points, not all).

Accurate Administration of Raskin Program with PKP Patterns. The accurate administration refers to the fulfilment of administrative requirements correctly and appropriately. Raskin Program with PKP Patterns implemented in North Central Timor Regency is different from the National Raskin Program. Since 2017, the term of Raskin (Beras Miskin) have changed into Rastra (Beras Sejahtera). Based on the description and results of interviews above, it was analyzed that the administration of the PKP Program was quite a lot, ranging from the regency to village level. The one becoming the obstacle was the administration at the village level, in which the formats were quite a lot and complicated. Therefore, the committees with low education background were difficult to follow the formats. It can be concluded that there are some requirements in the PKP Program, in this case referring to the forms that should be filled correctly. Based on this, it can be said that the accurate administration indicator of the Raskin Program with the PKP Patterns has not been implemented well.

Obstacles in Raskin Program Implementation with PKP Patterns:

Internal obstacles. There were still many obstacles in the implementation of the Raskin Program with PKP Patterns, hampering the long-term objectives of the PKP Program that is 
to achieve food security and food sovereignty for Beneficiary Families by providing new sources of livelihoods sustainably, encouraging the dissemination of eco-friendly agricultural systems through subsidized rice and optimizing the Raskin management for the Beneficiary Families in North Central Timor Regency. The limited land also became an obstacle in the Raskin Program Implementation with PKP Patterns because some of the farmer plantations were located around forest areas such as in Manusasi Village. This caused the extensification efforts done by the farmers (for achieving the purpose of Raskin Program using the PKP Patterns and dry land agroforestry system with 0.25 ha per year as well as making new farmland to be settled farmland) became difficult.

External Obstacles. In addition to internal obstacles, there were also obstacles coming from the outside of Beneficiary Families. The one was the policy formulation that was still difficult to be applied by the Beneficiary Families, for example cropping patterns that should be in line, making terracing, lack of fertilizer availability, and uncertain rainfall. The existing obstacles caused nonoptimal implementation of the PKP Program in North Central Timor. However, in each year, the program is evaluated and the results of the evaluation are used to make improvements.

\section{CONCLUSION}

The proposed evaluation model in the implementation of Raskin program with PKP patterns in North Central Timor Regency is the combination of evaluation teams. It is suggested that the Department of Agriculture as the Technical Team at regency level do an evaluation that involves the Combined Evaluation Team, in this case covering the Technical Teams at Regency, district and village levels. Moreover, the evaluation should also involve customary leaders in each village governed in the village regulations containing the rights and obligations as well as sanctions for Beneficiary Families if they neglect the plantation works or if they do not conduct the plantation works in accordance with the working norms defined in the Technical Guidance of the Department of Agriculture of North Central Timor Regency. Then authors suggest evaluation Model: Establishment of a Combined Evaluation Team consisting of the Technical Teams at the Regency, district and sub-district/village levels as well as customary leaders and community leaders.

\section{REFERENCES}

1. Anwas, O. M. (2014). Pemberdayaan Masyarakat di Era Global. Bandung: Alfabeta.

2. Dunn (2003). Pengantar Analisis Kebijakan Publik. Yogyakarta: Universitas Gajah Mada.

3. Kartasasmita, G. (1996). Pemberdayaan Masyarakat Konsep Pembangunan yang Berakar pada Masyarakat. Jakarta: Bappenas.

4. Mulyono, S. (2009). Teori Pengambilan Keputusan. Jakarta: LPFE UI.

5. Thoha (2002). Dimensi-Dimensi Ilmu administrasi Negara. PT Raja Grafindo Persada.

6. Wibawa, S. (1994). Evaluasi Kebijakan Publik. Jakarta: Intermedis.

7. Winarni, T. (1998). Memahami Pemberdayaan Masyarakat Desa Partisipatif dalam Orientasi Pembangunan Masyarakat Desa Menyongsong Abad 21: Menuju Pemberdayaan Pelayanan Masyarakat. Yogyakarta: Aditya Media. 